Yıldız, Ayhan; Cîyê Fonetîk, Fonolojî û Gramera Devoka Xerzan di nav Devokên Kurmancî û Dîyalektên Kurdî da The Journal of Mesopotamian Studies, C: 4/2, Summer 2019, s. 247-267 Doi: $10.35859 /$ jms.2019.559040

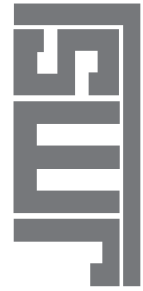

Makale Gönderim Tarihi: 29.04.2019

Makale Kabul Tarihi: 29.07.2019

\title{
CÎYÊ FONETÎK, FONOLOJÎ Û GRAMERA DEVOKA XERZAN DI NAV DEVOKÊN KURMANCÎ Û DÎYALEKTÊN
}

\section{KURDÎ DA}

\begin{abstract}
Ayhan YILDIZ*
KURTE

Hudûdên devoka herêma Xerzan, ji hudûdê bajarê Bidlîsê dest pê dike, heta hudûdê Mûş, Dîyarbekir, Sêrt, Batman û Mêrdînê dewam dike û digihêje heta sînorê devoka Torî ku di nav sînorên Mêrdînê da cih digire. Devoka Xerzan, di dirêjahîya domahîya dîrokê da neçar maye ku di bin desthilatdarîya dewletên curbicur da bimêne. Her çiqas zemanê berê li herêma Xerzan nufûsa ermenîyan jî hebûye, bes îro tenê şênîyên $\mathrm{ku}$ bi erebî, kurmancîya jor $\hat{\mathrm{u}}$ kirmanckî/zazakî/dimbilkî dipeyivin li vir dijîn. Zemanê ku ermenî li vir hebûn, dînî Îsewîyan jî hebûye; lêbelê îro tenê muntesîbên dînê Îslamê ku li ser mezhebê Sunnî-Şafî̀ ne li vir dijîn. Di vê xebatê da taybetmendîyên devoka Xerzan û dîyaleketa kurmancîya jêrîn û devokên din ên kurmancî yên mîna devoka Torê, Mêrdîn, Dîyarbekir û Serhedê digel hev hatine berawirdkirin. Li ser bingehê hewl hatîye dayîn ku tesbîta karakterên hevbeş ên devoka Xerzan û dîyalektên din, digel ên kurmancîya jêrîn bihê kirin.
\end{abstract}

Bêjeyên Sereke: Herêma Xerzan, Fonetîk, Fonolojî, Devok, Dîyalekt, Kurmancî

\footnotetext{
* Öğr. Gör. (Pey. Fêr.) Mardin Artuklu Üniversitesi,Türkiye'de Yaşayan Diller Enstitüsü, Kürt Dili ve Kültürü Anabilim Dalı. ayhanmeretowar21@gmail.com, Orcid: 0000-0002-8763-4182
} 


\title{
Garzan Ağzının Fonetik, Biçimbilim ve Dil Bilgisinin Kurmancî Lehçesinin A ğızlarında ve Kürtçenin Lehçeleri Arasındaki Yeri
}

\begin{abstract}
ÖZET
Garzan ağZı sınırları Bitlis ili sınırından başlar, Muş, Siirt, Diyarbakır, Batman ve Mardin sınırlarına kadar devam eder. Mardin bölgesinde yer alan Tori bölgesine kadar genişleyen Garzan ağzı, tarih boyunca çeşitli devletlerin egemenliği altında yaşamak zorunda kalmıştır. Garzan bölgesi, önceleri Ermeniceyi konuşan nüfusu olmasına rağmen, günümüzde Arapça ve Yukarı Kurmancî ile Kırmanckî/Zazakî konuşan bir nüfusa sahiptir. Ermenilerin burada yaşadığı dönmelerde Hırıstiyanlık dini de burada yaygın olmuşsa da, bugün sadece İslam dini ve Sünni-Şafî̀ mezheb müntesipleri burada yaşamaktadır. Bu çalışmada Garzan ağzının özellikleri, nasılki Aşağı Kurmacî lehçesiyle karşılaştırılmış, Kurmancî'nin Tor, Mardin, Diyarbakır ve Serhad ağızlariyla da karşılaştırılmıştır ve ortak olan karakterlerinin tespit edilmesine çalışılmıştır.
\end{abstract}

Anahtar Sözcükler: Garzan Bölgesi, Fonetik, Fonoloji, Ağız, Lehçe, Kurmancî

\section{The Place of Phonetic, Morfology and Grammar of Garzan Sub-dialect Among Other Sub-Dialects of Kurdmanci Dialect and Other Dialects of Kurdish}

\begin{abstract}
The borders of Garzan sub-dialect start from Bitlis province and reaches to the borders of Muş, Siirt, Diyarbakir, Batman and Mardin provinces. Garzan subdialect that reaches to Tori area of Mardin province has been under the sovereignty of different states through the history. Though there have been Armenian speaking community in the Garzan arae in the past, there are onylu Arabic, Upper Kurmancî, and Kirmanckî/Zazakî speaking communities at the present. In the times that Armenian were dwelled, Christianity were common in the Garzan area, however, today there are only beliewers of Sunnah-Shafi sect of Islam live there. In this study we compare the features of Garzan sub-dialect with Kurmancî dialect as well as with the Tor, Mardin, Diyarbakır and Serhad sub-dialects of this dialect.
\end{abstract}

Key Words: Garzan area, Phonetics, Phonolgy, Sub-Dialect, Dialect, Kurmancî

\section{Destpêk}

Herêma Xerzan, bi taybetiyên xwe yên devokî ji devokên din ên dîyalekta kurmancî cîya dibe. Ev rewşa wê ya cîyawaz, helbet, bi rabirdûya wê ya sîyasî û dîrokî ve têkildar e. Ji ber ku kurmanc û ereb li vê herêmê, bi taybetî jî li navend û gundên derdora qezaya Sasonê û Hezoyê di nav hev da dijîn, bivê nevê karîgerîya vê pevrebûnê teyîsîye ser vê devokê. Berî ku em dest bi taybetmendîyên devokê bikin, em pêşî dest bi dîroka wê ya sîyasî bikin, li gor qenata me dê çêtir be.

Herêma Xerzan ku ji gelên cîya cîya û ji dewlet û dînên cîya cîya ra malovanî kirîye, çawa ku ketîye bin karîgerîya van çand û şaristanîyan, wisa jî helbet ji hêla zimanên wan ve jî reng û rû girtîye. Dibe ku fonetîka vê devokê, ketibe bin bandora fonetîka van zimanan. Meriv bi hêsanî dikare dîyar bike, çawa ku fonetîka hemû devokên bakur ketine bin tesîra fonetîka zimanê tirkî, helbet zimanê erebî ku li vê herêmê aktîf e, dibe ku karîgerî li fonetîka wê kiribe. 
Çawa ku fonetîka kurmancî di devoka herêma Xerzan da diguhere, zayenda bêjeyên navdêr jî bi temamî ji hemû devokên din ên kurmancî cîya bûye, hema mîna kurdîya babanî zayenda hemû cure bêjeyên navdêr bûye wekî hev. Bêjeyên mîna "dayk", "xwişk" û "met" ku zayenda wan makî ye, di devoka kurmancîya Xerzan da gişt bi awayê nêrî dikevin îzafeyan.

Cihderka dengdêra "a"yê di devoka Xerzan da ji alîyê fonetîkê ve bi temamî dişibe kurdîya babanî/naverast. Axiverên vê devokê, tîpên xwe yên nedengdêr, mîna nedengdêrên kurmancîya jêrîn bi awayekî çist û çeleng bi lêv dikin. Kurmancîya Xerzan ji alîyê fonetîka dengdêrên xwe ve çawa ku dişibe devoka Torê, bi pareke pirtir dişibe fonetîka kurmancîya xwarê/jêrîn.

\section{Rêbaza Lêkolînê}

Devoka Xerzan ku bi awayekî balkêş dişibe dîyalekta kurmancîya jêrîn û di nav hemû devokên din ên kurmancîya jorîn da xwedî cîyekî xweser e, bi çi awayî ketîye vê rewşê, kengê bi zayenda navan ji devokên din ên kurmancî veqetîyaye, ji ber çi sedemê dişibe dîyalekta kurmancîya jêrîn, hêjayî lêkolînê bû. Bi qasî ku pê hisîyame, li ser vê devokê xebateke zimannasî nehatîye kirin. Ji ber vê çendê armanca min bi vê lêkolînê ew e ku bi qasî taqeta xwe hîn bibim bê ka ev devok xwedan çi taybetîyan e, bi çi awayî teşe girtîye û heta roja me berdewam kirîye.

Agahîyên derbareyê fonetîk, teşenasî, gramer û sentaksa devoka Xerzan ku di vê gotarê da behsa wan hatiye kirin, ji wan daneyên xebata qadî ku min bi xwe berhev kirine, peyda bûne. Digel ku ez şênîyekî vê herêma devoka navbangî me jî, dîsa min dengê axiverên vê devokê qeyd kirine û a niha qeydên wan li ber destê min mewcûd in.

Di vê xebatê da min ji rêbazên zimanî yên zanistî, ne rêbaza dîyakronîk; bes rêbaza senkronîk bingeh girt. Çawa ku Bingöl (2017: 90) amaje pê dike, ji bo rêbaza dîyakronîk, pêdivî bi metnên qedîm ên berê hebû. Çi heye ku tu deqeke/metneke nivîskî ya berê bi destê min neket. Ji lew ra taybetmendîyên devoka Xerzan ku min hewl da tesbîta wan bikim û bi devok û dîyalektan ra berawird bikim, tenê yên xasî bi axaftina roja me ne.

\section{PÊNASEYÊN BÊJEYÊN TAYBET ÊN HERÊMA XERZAN}

\subsection{Bêjeya "Xerzan"}

Koka bêjeya Xerzan, li gor qenaeta min ji غرز an ji غرض غرض "xerz" ango "gherz" tê. Digel ku di zimanê erebî da bêjeya غارض "xerez" heye û wateya wê "qesd" e û ev her du bêje dişibin hev jî, ji çavkanîyên dîrokî dîyar dibe ku guhertoyeke wê ya din jî heye. Li gor M. E. Zekî, têkilîya bêjeya Xerzan û Erzen digel hev heye (بيح، 3645). Li gor komisyona akademisyenên Universiteya Atatürk a Erzurumê qeyd kirîye jî, têkilîya vê bêjeyê, bi bêjeya "erzen" ra heye: "Di pey sedsala 4an da, li ser parvekirina herêma Erzen, Pers û Bîzansî ketine şer û herban. Ev şer, heta dawîya sedsala 5an domîyane. Di vê serdemê da 
Bîzansîyan, ji bo parastin û berterefkirina êrişên li sêkoşeya Sason, Hezo û Bedlîsê, gelek keleh ava kirine (Komisyon, 2011). Keleha bi navê Rebetê li gundê Yanıkkayayê/Smayilkayê dimêne. Ev dever, $18 \mathrm{~km}$. dûrî navçeya Kozluk/Hezoyê ye û li bakurê wê ye."

\subsection{Bêjeya "Hezo"}

Kurmancên vê deverê, bêjeya "Hezo"yê bi awayê herfa z ya erebî û j (zeyna)ya erebî bi lêv dikin: حزو y حاضي Heger em li bêjeya erebî binihêrin, em dê bibînin ku gelê tirk vê bêjeyê bi awayê "kadı"; kurmanc bi awayê "qazî" bi lêv dikin. Nexwe kurmanc, herfa ض ya erebî, bi awayê "z"yê bi lêv dikin. Dibe ku

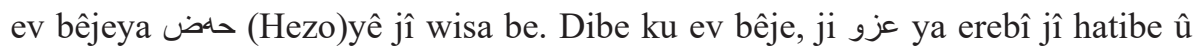
dibe ku herfa و "û" veguherîbe herfa "o"yê.

Navê navçeya Hezro ku li ser Dîyarbekirê ye jî bi fonetîka xwe dişibe navê Hezoyê. Bêjeya Hezro, ji zimanê erebî tê û awayê wê yê rasteqîn حضرو ye. Wateya wê, keskî ye. Wisa dîyar e ku ev herfa g veguherîye herfa "o"yê. Navên mîna Zoqê û Zoqeydê jî li hêla Gurdilan hene.

\section{Hudûdê Cografî̀ yê Herêma Xerzan}

Pîvherêma navçeyê, 1101 kîlometrekare ye. 69 gund û 115 mezra li ser wê ne. Di navenda wê da 25 tax hene. Ji ber ku wekî derîyekî Rojava di navbera Rojhilat û Serhedê cîyê xwe digire, di dîrokê da behsa wê bi berfirehî hatîye kirin. Herêma Xerzan wekî cografya, ji alîyê şaroşkeyan/navçeyan ve ji hêla başûr ve ji bajarokê Qubînê (Beşîî) dest pê dike tê Misircê (Kurtalan) û diçe heta bajarokê Hewêlê (Baykanê); ji hêla bakur ve ji bajarokê Hezo (Kozluk)ê dest pê dike diçe digihîje heta navçeya Sasonê. Hudûdê herêmê, bi çemê Batmanê ku di navbera sînorê Dîyarbekir/Amid û Batmanê da diherike bi dawî dibe. Li hêla Bidlîs û Sêrtê jî çemê ku ji Bidlîsê tê diherike hêla başûr, bûye sînorê herêmê. Ji bakûr ve çîyayê Mereto û Helqîs û Kopê, wekî sînorên siruştî yên herêmê tên zanîn.

Li gelîyê Xerzan, xiravabajerek heye ku wekî şehrekî kavil, a niha jî li ber çavan e û lêkolînên arkeolojîk li ser wê hatine kirin. Van çavkanîyên ha, ev der wekî şehrekî entîke bi nav kirîye û vê agahîyê li ser wî didin. Li mezraya Yeşilyurta ku li ser gundê Oyuktaşê ya navçeya Hezoyê ye, li ber qeraxê Çemê Xerzan e, lêkolînên ser-rûyê erdê hatine kirin, kavilên vî şehrê entîke derketine holê. Îca gundikê Yeşilyurt, li ser xerabeyên Erzenê hatîye avakirin. Lewre ev gundikê Yeşilyurt, di meha çile ya 2008an da li gor Qanûna Parastina Hebûnên Çandî û Siruştî, ya bi hejmara 2863yan, wekî qada sît hatîye îlankirin. Ji Mîrektîyên tirk, Dilmaçoğullarîyan, şehrê Erzen, ji xwe ra kirîye payitext. Piştî Şerê Melazgirê, begên din ên tirk, bi ser Enedolê ve cerd kirine û di pey fethên serkeftî da, Selçûkîyan, Erzen û derdora wê, weke tîmar daye Mehmet Begê Dilmaçoğlu. Wî jî, sala 1085an, li vê herêmê begîtîya xwe damezirandîye. Dilmaçoğullarîyan di dîrokê da wisan zêde deng venadebe jî, wan ev erd, maweyeke dirêj di bin 
hîmayeya xwe da girtine. Akkoyunîyan, sala 1395an, ev begîtî bi temamî xerab kirîye. Erzen, di çavkanîyan de, ji payitextên herî mezin ên Serdema Navîn hatîye hesibandin. Di hîyama nîveka sedsala 13 an de, cografyagerê navdar ê Îslamî, Îbn Şeddad, ev şehr zîyaret kirîye û dîtinên xwe wiha dîyar kirîye: "Li cîyekî berfireh ava bûye, xan û medreseyên wî hene, muferreh e. Bi 32 bircan dormedorkirî ye." Bi xebatên zanistî derketîye holê ku Erzen, a Îslamê ye. Erzena Îslamî, di Serdema Navîn de, yek ji wan şehrên girîng ên mîna Dîyarbekir, Mêrdîn û Heskîfê ye. Hetta tê dîyarkirin ku wê serdemê, Erzen ji hêla qada xwe ya bicihbûnê ve, ji şehrê Dîyarbekirê mezintir bûye (Komisyon, 2011: 53-54). Wekî din, hin agahîyên ku li ser şehrê Erzenê hatine tomarkirin radigihênin ku kavilên şehrê Erzena Entîke, li gundê Yunuslara ku li ser nevçeya Misircê (Kurtalana) Sêrtê ye hene; îca ev kavilên ku li hêla gundê Hezoya Batmanê ne, beşa wî ya havîngehî ne. ${ }^{1}$

\subsection{Hudûdê Cografî yê Devoka Xerzan}

Herêma Xerzan digel ku wekî cografya, ji alîyê şaroşkeyan/navçeyan ve ji hêla başûr ve ji bajarokê Qubînê (Beşîrî) dest pê dike ber bi bakur ve tê Misircê (Kurtalan) û diçe heta bajarokê Hewêlê (Baykanê); ji hêla bakur ve ji bajarokê Hezo/Kozlukê dest pê dike ber bi rojava ve diçe digihêje heta navçeya Sasonê jî, ji hêla "Devoka Xerzan" ve di nav sînorên van şaroşkeyan da li cîyekî lokal bi sînor dibe. Şaroşkeya Qubînê, bi devoka gund û eşîrên nav hudûdê xwe, bi temamî ji devoka Hezo, Misirc, Hewêl û Sasonê cîya ye. Navenda navçeya Hezo, Misirc, Hewêl û Sasonê di nav sînorên vê devokê da ye; lêbelê navenda navçeya Qubînê, ji ber ku ji eşîrên mîna Reşkotan û Elikan pêk tê, ne di nav sînorên devoka Xerzan da ye. Digel vê jî, qismekî mezin ji şênîyên vê navçeyê, piştî salên 1980yî ji hêla çiyayên Hezoyê hatine li vir bi cih bûne û bi devoka Xerzan dipeyivin.

Çawa ku navenda navçeyên mîna Hezo, Sason, Misirc û Hewêlê, hema hema bi temamî di bin karîgerîya kurmancîya Xerzan da ne, çend gundên nêzî navenda van navçeyan jî bi temamî di bin tesîra vê devokê da ne. Sînorê wan gundên nêzî navenda Sason û Hezoyê ku bi devoka Xerzanîyê dipeyivin, ji 40 km.yan nabihure.

Gundên mîna Timoq, Daragûzê, Mangîk, Bariştirm, Melkîşa û Dêrayê ku li hêla rojavayê Hezo dimênin, bi devoka Hezoyê dipeyivin; bes ji sînorên van gundan pê ve gundên mîna Baqînê, Kenik, Xoxê, Mexsûdîkê, Qawecî, şaroşkeya Kanîyahenê, Kanîkê, Selîvê, Zîlîya, Dêle, Hiskûtê û Şelmo ku wekî gundên eşîra Bekiran tên zanîn, bi kurmancîyeke wisa dipeyivin ku ji hêla devokê ve bi tu awayî naşibe devoka Xerzan.

${ }^{1}$ Ji bo agahîyên berfireh bnr. http://www.haberpen.com/antik-kent-iki-arada-bir-derede-kaldi-haberi/ 02 . 03. 2015. 
Li hêla navçeya Sasonê jî gundên nêzî navenda wê ne tê da, ew gundên ku li hêla herêma Xerzan dikevin û bi qasî 10 km.yan nêzî vê navçeyê jî dîsa bi devoka Xerzan napeyivin. Gundê Kanîyanavo, Kanîyaberê, Cewzîkê, Holê, Rebetê, Baqînê, Smaîlka, Kififê û Teraş ku dîsa bi qasî 20-30 km.yî nêzî Sasonê ne, bi temamî bi kurmancîyeke derveyî devoka Xerzan dipeyivin.

\section{EŞîRÊN HERÊMA XERZAN}

Eşîra Bekiran, ji gundê Qawecî (Kahveci) ku li rojavayê başûr ê Hezoyê dikeve dest pê dike tê heta nehîyaya Kanîyahenê (Bekirhan), gundê Melkîşa, Şelmo, Xoxê/Sûcê, Baqînê, Smaîlka (Yanikkaya), Kanîyaberê, Rebetê, Dehlikê, Kifîfê, Holê û Cewzîkê. Li hêla başûrê Hezoyê ku ber bi Batmanê ve diçe, eşîra Reşkotan heye. Li milê rojhilatê Hezoyê ku ber bi Weyselqeranî û Hewêl (Baykan)ê ve diçe, eşîra Etmankan heye. Li hêla bakur, di navbera Hezo û Sasonê da, di nav çîyayên bakurê Herêma Xerzan da, eşîrên ereb ên mîna Şîgo, Bidrî, Celalî, Dêrxanî, Kendo, Şero û Şêxan hene; ji eşîrên kurdan jî eşîra Xîyan, Timoq, Kurrî/Xerzî û Bozikan hene (Naîma, 2018).

\section{RABIRDÛYA DÎROKî YA SÎYASî Û MÎREKTÎYÊN HERÊMA XERZAN}

Çawa ku Mîrektîya Xerzan hebûye, mîrên cîranên wî yên mîna Mîrektîya Sasonê, Mîrektîya Heskîfê û Mîrektîya Meyafariqînê jî hebûne. Çi heye ku di nav Mîrektîya Xerzan da tenê Mîrnişîna Hezo û Mîrnişîna Sasonê hene. Jixwe kurmancîya van her du deveran mîna hev e. Ji bo ku meriv bikaribe li ser devoka herêma Xerzan bigihêje encameke baş, helbet pêdivî bi ronkirina rabirdûya wê ya dîrokî heye. Ji lew ra li vir, me cih da vê binbeşê.

\subsection{Mîrektîya Hezo}

ji ber ku di cografyayeke krîtîk û girîng da ava bûye, ev der tûşî gelek destguherînan bûye û heta serdema desthilatdarîya îslamî negihaştîye îstîqrarê. her çiqas di serdema îslamê da carina ketibe bin desthilatdarîya bîzansîyan jî, bi giştî di destê rêveberên muslim da maye. çawa ku di serdema xelîfe umer da devera cezîre ketîye bin desthilatdarîya sîyasî ya îslamî, êdî di serdema hz. usman û hz. elî da jî di destê musliman da maye. xelîfe umer (634-644), sala 17 yê koçî, se'd bin ebî weqqas û 'îyaz b. xenem wekî fermandarên artêşê şand ser cezîreyê. herêm, ji ber ku di navbera çemê dicle û çemê firatê da cih digire, bi vê bêjeya "cezîre"yê hatîye binavkirin. ev dever, di nav xwe da dabeşî du herêman bûye: dîyarê misir û dîyarê bekir. li ber ava çemê dicle û firatê gelek beled û keleh ava bûne û wê serdemê di bin destê bîzansîyan da bûne. herêma dîyarê bekir, ji herranê heta ruha, reqqe, re'su'l-'eyn, nuseybîn, sincar, xabûr, mardîn, amid, meyafariqîn, mûsul û yên din pêk tê. piştî fetha şam û rraqê, xenem bin îyaz, piştî sulha ruhayê ku herran, bi fermandarê musliman ra li hev dike, êdî fermandar îyaz, eba mûsa el-eşerî dişêne ser alîyê nuseybînê; umer bin se'd jî dişêne hêla re'su'l-eynê. îca îyaz bi xwe jî berê xwe dide hêla darayê û vê 
deverê digire bin destê xwe. eba mûsa şênîyên nuseybînê ra, fermandarên din jî bi xelkê deverên din ra bi awayê herî xweş li hev dikin (2005/1426:127128). di pey wan da ku serdema emewî û ebbasîyan tê, dever her bi nasnameya xwe ya îslamî maye. dewleta îslamî ya xanedanê kurd merwanî jî, heta hatina selçûqîyan li vê deverê bûne desthilatdar. piştî selçûqîyan eyyûbîyan ev der girtîye bin destê xwe. piştî desthilatdarîya eyyûbîyan, heta serdema osmanîyan mîna mîrektîyên din ên herêmê, ev der jî bi awayê sîstema rêvebirina mîrektîyan bûye.

Di pey çar xelîfeyên mezin da hemû herêm, mîna Hezoyê, di salên 906an da ketîye bin desthilatdarîya Dewleta Emewî, peyre jî ya Dewleta Ebbasîyan. Di serdema xelîfetîya Ebbasîyan da Hemdanîyan di nav salên salên 906 û 9901 da li vê derê hukum kirîye. Di pey wan da Merwanîyan di nav salên 990 û 1096an da li herêmê xanedanîyeke dewletî ava kirîye û li vê deverê hukum kirîye. Tugrul Begê Selçûqî di nav salên 1056 û 1057an da tê serfera herêmê û wê dixe bin destê Selçûqîyan. Sultanê Selçûqî Melîkşah, piştî ku payîtexta duyem a Merwanîyan Silvanê sala 1085an dixe bin destê xwe, kelehên din ên mîna Mêrdîn, Sêrt, Erzen û Heskîfê û dormedorên wan jî dibin tabiê/peyrewê wan (Sevim \&Yücel, 1989: 93). Muhtemelen devera herêma Xerzan, kelehên Sason û Hezoyê jî wê hingê ketîye bin desthiltdarîya Selçûqîyan.

\subsection{Mîrektîya Sasonê}

Mîrê Sasonê, ji nesla Mîr Îzzeddînê Bedlîsê ye û muqabilî eşîra Rojkî ye. Çar şaxên wê hene: Şîrawî, Yabûsî, Sûsanî û Tamûkî. Tevî Erzenê eşîra Xaldî, Dêrmexanî û Ezîzanî ketine bin desthilatdarîya Mîrê Sasonê. Li gor Şerefnameyê, damezrînerê vê mîrektîyê Mîr Ebûbekir e û di serdema Akkoyunîyan da hatîye damezrandin. Vê mîrektîyê heta serdema Şah Smaîl dewam kirîye. Piştî Şerê Çaldiranê ketîye destê Osmanîyan. Bi Osmanîyan ra Keleha Erzenê jî ketîye destê Mîrektîya Sasonê. Li ser vê, navbera wî û Mîrê Heskîfê xerab bûye (Zekî Beg, 2010: 517). Çi heye ku devoka herêma Bidlîs û Sasonê naşibe hev.

Mîrektîya Sason-Hezoyê, di serdema Elî Beg b. Mîr Ebû Bekir da bû tabiê Şah Smaîlê Sefewî; di serdema Muhemmed b. Elî Beg da li cem Yavuz Sultan Selîm cih girt û di Sefera Misirê da li hember Çerkezan ket şerekî dijwar. Ji ber wê, Yavuz Sultan Selîm, birêvebirina Mîrektîya Sason-Hezoyê da destê wî. Erzen jî lê zêde bû û piştî vê, ew birayê wî Hizir Beg b. Elî Beg ku li ser daxwaza serokeşîran bûbû rêvebir, ji vê wezîfeyê, li ser hemdê xwe feraxet kir, ji Keleha Sasonê derket û çû li Hezoyê bi cih bû. Mîrê Heskîfê Xelîl Beg, nexwast ku Keleha Erzenê radestî wî bike, lewre Muhemmed b. Elî Beg bi piştgirîya Mîrê Bidlîs û Cizîrê çû ser Keleha Erzenê û ev der girt bin destê xwe. Ji eşîrên Heskîfê yên mîna Xaldî, Dirmîgarî û Ezîzan jî bûn alîgirê wî. Sultan Suleyman Xan, fermannameyek ragihand û tê da hukumdarîya Sason-Hezoyê da Bahaddîn Beg b. Elî Beg (Zekî, 1945/1364: 369). 
Ji çavkanîyan (Zîllî, 2006: 476) dîyar dibe ku li zozanên vê derê kurdên Xaldî, Çeknawî û Zebarî hene. Piştî salên 1869an Xerzan, wekî qezayekê bi ser Lîvaya Sêrtê ve hatîye zêdekirin; Hezo jî, wekî qezayekê li ser Xerzanê ye. Sala 1884an Hezo, wekî qezayekê li ser Sêrtê xuya dike û Sêrt jî, wekî sancaxekê li ser welayeta Bidlîsê ye (Falay \& Uymaz, 2007: 153). Sala 1890î, hejmara şênîyên qezaya Hezoyê 10 hezar e, 5 hezarê wê muslim, 4 hezarê wê ermenîyên gregoryan; hezarekê wê jî ermenîyên katolîk in (Saraçoğlu, \& Y1ldız, 2007: 622630). Şemsettîn Samî radigihêne (Sami, 1996: 29) ku Sason li ser sancaxa Mûşê bûye; Mûş jî li ser welayeta Bidlîsê bûye. Samî dîyar dike ku hejmara şênîyên qezaya Hezoyê, digel 119 gundên wê gihişstîye 20101ê. Zemanê berê, digel ku ehalîyê wê 60 hezar bûye; peyra çi bûye nahê zanîn. 10370yî wê muslim, 8389ê wê ermenî, 372yê wê qiptî û 970yê wê êzîdî ne.

\section{FONETÎKA DEVOKA HERÊMA XERZAN}

\subsection{Cihderka Dengdêrên Dirêj}

\section{[a]}

Cihderka dengdêra dirêj [a]yê dişibe dengdêra [a]ya erebî. Ji ber ku ereb û kurd li bajarê Hezo û Sasonê û gundê mîna Xelefan digel hev dijîn, dibe ku ev deng ketibe bin karîgerîya fonetîka erebî. Bi tarîfeke din, ew [a]ya ku bi awayekî normal ji devê merivan derdikeve û di devokin din ên kurmancî da heye, di devoka Xerzan da tuneye; lêbelê bi awayekî gelek balkêş bi temamî di dirûvê [a]ya kurmancîya jêrîn (kurdîya naverast) da ye. Axifgêrên Xerzî, dengdêra [a]yê bi awayê axiverên Torî ku devokeke kurmancîya jorîn e derdixin. Cihderka [a]ya wan, nêzî cihderka dengdêra [ê]yê ye.

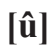

Dengdêra [û]yê nêzî dengdêra [o]yê ye. Axiverên vê devokê, vê dengdêrê bi awayekî ku ji devokên din hîn dirêjtir be bi lêv dikin û bi terzekî şedîd ji hinava xwe derdixin.

\section{[ê]}

Ev dengdêr mîna dengdêrên di ên dirêj, ne bi awayê devokên din ên kurmancî; bes tam bi awayê dîyalekta kurmancîya jêrîn (kurdîya naverast) tê bilêvkirin û axiverên wê, hundirê gewrîya xwe hinekî diguvêşin û wê ji kûranîya singê xwe derdixin.

\section{[î]}

Awayê bilêvkirina vî dengî yê devoka Xerzan, ji devokên din ên kurmancî cîyawaz e. Axiverên wê, bi awayekî narîn û nazik wê ji kûranîya hinava xwe derdixin. 


\section{[o]}

Axiverên devoka Xerzan, bi piranî dengdêra [o]yê bi awayekî ku dûrî [o]ya devokên din be bi lêv dikin û wê ji jora gewrîya xwe derdixin. Gava ciwanekî ji gundê Mangîk bêjeya "qoq" bi lêv dike, nedengdêra [o]yê wekî dengekî ku di navbera [u] û [o]yê de be derdixe.

\subsubsection{Cihderka Dengdêrên Kurt "[e], [i], [u]"}

Rêjeya bikaranîna dengdêrên kurt di devoka Xerzan da hindik e. Ew dengdêra [e] ji nav dawîya esmanê devê xwe derdixin. Dengdêra [i], bi dengekî narîn û henûn tê derxistin. Tişsê ku heye, cihderka dengdêra [u]yê, nêzî cihderka dengdêra [û]yê ye. Heta van salên dawîn hinek dormedoran li dengdêra [i], dengdêra alfabeya tirkî [1] bi kar dianî û îro jî dewrûberên ku kirmanckî wekî zimanekî xweser dihesibînin, di alfabeya xwe da vê dengdêra alfabeya tirkî bi kar diênin; çi heye ku di devoka Xerzan da bi awayekî gelek zêde aşkera dengê [i] derdikeve.

\subsection{Cihderka Nedengdêran}

Axiverên devoka Xerzanîyê, hemû nedengdêrên xwe, bi awayê çist, çeleng û hêzdar bi lêv dikin. Awayê bilêvkirina nedengdêrên vê devokê, bi awayekî gelek zêde dişibin kurdîya babanî û soranî ku jê ra kurdîya naverast tê gotin (سلهادى ئيير اهيمى 1396: 29).

\subsubsection{Cihderka Nedengdêra " $r$ "yê}

Çawa ku zimanewanê kurdîya naverast Wirye amaje pê dike (Emîn, 2009: 105106) digel ku zimanê kurdî û erebî di şeş dengên mîna [r], [J] [ح] [rr], [ص], [س], [Јّ] da hevbeş in jî; di sîstema nivîsîna nedengdêrên [r]ya zirav û [r]ya stûr [ير] da ji hev cîyawaz in û wekî du fonemên cîyawaz ji devê merivan derdikevin. Awayê derxistina nedengdêra [r]ya stûr, di derbirînê da zarî ye, gava ku meriv bixwaze vî dengî derxe, zimanê xwe ber bi pêş ve dibe û bi awayê lerzok derdixe (Xoşnaw, 2013: 26).

\subsubsection{Cihderka Nedengdêra [L]yê}

Di sîstema nivîsîna nedengdêra [L]ya zirav û [L]ya stûr" da cîyawazî heye wekî du fonemên cîyawaz ji devê merivan derdikevin. Ji lew ra di alfabeya erebî ya kurdîya naverast da ji bo ku ferqa navbera [L]ya stûr [ J゙ ji [L]ya zirav bihê kirin, zimannasan (Emîn, 2009: 107) nîşaneya "v"ê li binê [L]ya stûr danîye. Çawa ku Xoşnaw (2013: 26) cihderka wê tarîf dike gava meriv vî dengî di weqtê derbirînê da bi lêv dike, serê zimanê xwe ber bi pêş ve dibe û hinekî giran dike û wisa derdixe. 


\section{FONOLOJÎYA DEVOKA HERÊMA XERZAN}

\subsection{Dengdêr}

\subsubsection{Dengdêra $[A]$}

Axiverên devoka Xerzan, çi di serê bêjeyan da be, çi di nîvê bêjeyan da be û çi jî di nîvê bêjeyan da be, herfa [a]yê, hemin hertim bi awayê narîn û kubar bi lêv dikin.

\subsubsection{Dengdêra [E]}

Di devoka Xerzan da dengdêra [e]yê gava wekî gireya erênî tê ser navdêran, nêzî dengê [a]yê ye: Bajarê Hezoyê xweş $\boldsymbol{e}$.

Lêbelê gava axiverekî devoka Torê, heman risteyê saz dike, dengê [e]yê bi temamî vedigherîne [a]yê: Bajarê Hezoyê xweş a.

Wisa xuya dike ku ev deng ne di devoka Mêrdîn û Dîyarbekirê da heye, ne jî di devoka herêma Serhedê da.

Ji bilî devoka Xerzan, devokên din ên derdora vê deverê, -eşîra Reşkotan ne têda- heta devoka eşîra Badikan û herêma Erxenîya Dîyarbekirê, Qerecdaxê, herfa [e]yê, di dawîya bêjeyan da, çi fiîl bin, çi jî navdêr bin, vediguherînîn herfa [i]yê:

"Elî diçe malê." > "Elî diçi malê."

"Ew merivekî baş $e . ">$ "Ew merivekî baş $i . "$

\subsection{Nedengdêr}

\subsubsection{Nedengdêra $[B] y \hat{e}$}

Axiverên devoka Xerzan, mîna axiverên devoka Bekiran û Deşta Gewran, herfa [b] bi tu awayî venaguherînin herfa [w], yan jî [v]yê. Tîpa [b] di her rwşê da [b] ye.

\subsubsection{Nedengdêra $[L]$}

Di devoka Xerzan da nedengdêra [L]yê bi du awayan di nav axaftinê da cih digire: [L]ya zirav û [L]ya stûr. Ji lew ra di alfabeya kurdîya naverast da ji bo ku ferqa navbera [L]ya stûr ji [L]ya zirav, zimannasan (Emîn, 2009: 107) kovika "v"yê li binê [L]ya stûr danîye.

Bêjeya "mal" dibe ku ji ber dengdêra [a]yê be ku nedengdêra [L]yê stûr tê bilêvkirin. Gava herfa [L] di bêjeya "bila" da dihê bikaranîn, herfa [L] zirav dibe. Ji van rewşan dîyar dibe ku çawa nedengdêr stûr in, dengdêrên bi wan ra jî stûr dibin. Barê stûrîyê ne tenê li ser nedengdêran; bes li ser dengdêran ne jî. 


\subsubsection{Nedengdêra $[R]$}

Çawa ku di devokên din ên kurmancî da jî heye, di devoka herêma Xerzan da jî du cure nedengdêrên [r]yê hene: [r]ya zirav û [r]ya stûr. Çawa ku di kurdîya naverast (babanî-soranî) (Emîn, 2009: 106) da du dengên nedengdêra [r]yê hene, di vê devokê da jî bi awayekî zelal xwe didin der. Ji lew ra di alfabeya erebî ya kurdîya naverast da ji bo ku ferqa navbera van [r]yan, zimannasan (Emîn, 2009: 105-106) nîşaneya "v"yê li binê [r]ya stûr danîye; lêbelê di alfabeya latîn a kurmancî da ev cîyawazîya van tîpan nehatîye destnîşankirin. Di van risteyên jêr ên devoka Xerzan da nedengdêra [r] stûr e:

Dibêjin derew e. (Tarduş) ${ }^{2}$

Heta ku ji we bê, derewan mekin. (Wext Çawa Derbas Bû,, 02.11.2018)

\subsection{Rûdanên Nedengdêran}

\subsubsection{Pevguherîna $[R]$ û $[L] y e ̂$}

Meyla devokên derveyî Herêma Xerzan, di bilêvkirina nedengdêra [r] û [L]yê da li ser nedengdêra [r]yê ye; lêbelê ya devoka Xerzan, li ser nedengdêra [L]yê ye.

\begin{tabular}{|l|l|}
\hline Devoka Xerzan & Devokên Din \\
\hline Bila bihên. & Bira bihên. \\
Bila be. & Bila be. \\
\hline
\end{tabular}

\subsubsection{Pevguherîna [v] û [f]yê}

Axiverên devoka Xerzan, cîyê herfa [v]yê didin herfa [f]yê. Mesela bêjeya "mirov" bi awayê "mirof" bi lêv dikin. ${ }^{3}$

\section{GRAMERA DEVOKA XERZAN}

\subsection{Gireya Dema Bihê/Dahatû}

Digel ku îro partîkela dema dahatû, di devokên din ên kurmancî da $\hat{e}$, dê û wê ye, ye; li herêma Xerzan, li navenda Hezo, Comanîyê û Babosîyê, di nav

\footnotetext{
${ }^{2}$ Îbrahîm Tarduş ku li Unîversîteya Mardîn Artuklu akademîsyen e, bi eslê xwe ji herêma Xerzan e û ji bo vê xebatê min pê ra hevpeyvîn kirîye.

${ }^{3}$ Ji ber ku herêma Xerzan xwedan cografyayeke zozanî ye, bedena merivan li vir rehet e, dibe ku ji ber vê avantajê be ku axiverên wê bi awayekî siruştî karîne zimanê xwe henûn û çeleng bikin. Ji bo delîlê vê taybetmendîyê, meriv dikare li ser youtubê, https:/www.youtube.com/watch? $\mathrm{v}=$ inNoUWCHHM0\&t=731s li vîdeoya bi navê seyda abdurrehman inal kozluk binihêre .
} 
axiverên vê devokê da gireya/partîkela dema dahatû, "tê" ye: Ez tê werim. Min tê bigota. Ew tê bê.

\subsection{Gireya Karê Demî}

Gireya kesê duyem ê yekhejmarî ku tê ser navdêran, meylî ser dengê "a"yê dike ku dişibe devoka Herêma Torê: Ew a. Ew baş a. Ew şareza ya.

\subsection{Daçek}

\subsubsection{Paşdaçeka "de/da"}

Her çendî di ristesazîya vê devokê da paşdaçeka "de" kêm be û bêhtir pêşdaçeka "li" tê bikaranîn jî, dîsa "de" heye. Carina ev paşdaçeka "de" bêyî pêş̧açeka wê "di" tê. (Hev. Î. Tarduş). Paşdaçeka "de" bi awayekî zelal û îstîqrarî bi awayê "de"yê tê bikaranîn û bi qasî ku me ji axiverên a niha bihîst paşdaçeka "da" kêm e. Paşdaçeka "de" di nav axiverên Gurdilanî/Misircî de jî bi awayekî zelal tê bilêvkirin. Ne bi awayê "da" ne jî bi awayê "di" ye; rasterast tim bi awayekî "de" ye.

\subsubsection{Paşdaçeka "re/ra"}

Paşdaçeka "re" bi awayekî zelal û îstîqrarî bi awayê "re"yê tê bikaranîn û bi qasî ku me ji axiverên a niha bihîst paşdaçeka "ra" zaf kêm e û bi awayekî biîstîqrar bi awayê "re" ye.

\subsection{Nav}

\subsubsection{Zayenda Navan}

Hemû navdêr, li Herêma Xerzan, di devoka Hezoyê da ji hêla zayenda xwe ve bi awayê nêr tên bikarênan:

Bavê min

Dîyê min

Xoyê min

Tiştê ku heye ev zayend, hinekî ji zayenda babanî-soranî cîyatir e. Ev zayenda vê devokê kurdîya şêxbizinîyan tîne bîra me. Li gor dîroknasan şêxbizinî çawa ku li cîyên mîna Aksaray, Enqere, Konya, Adapazari, Amasya, Samsun, Sînopê yên turkîyayê hene, li deverên mîna Kexta, Dîyarbekir, Wan, Kerkûk, Xaneqîn û Elamê jî dijîn (M. Salih Batirhan, 2014: 85). Di vê kurdîyê da jî navdêrên makî di îzafeyê da mîna navdêrên nêr gireya zayendê digirin:

\section{Jina rind, dibe Jinê rind}

Jineke rind, dibe jinî rind (Batirhan, 2014).

Carina meriv dibêje gelo ev têkçûna zayenda mê di devoka Hezoyê da ji ber jîyana wan a digel gelê ereb e, yan na? Gava meriv bala xwe dide bajarê Mêrdîn 
û Sêrtê, li wê derê jî ereb û kurmanc ji qedîmî zeman ve di nav hev da dijîn; bes zayenda kurmancî xwe diparêze. Çi heye ku divê meriv vê jî bizanibe ku niştecîyên desthilatdar ên bajarê Mêrdîn û Sêrtê ji weqtakî dûr û dirêj ve ne kurmanc; bes ereb bûn. Îca gava em li bajarê Hezo û Sasonê dinihêrin, niştecîyên desthilatdar ên van her du bajaran ji qedîmî zeman ve kurmanc bûne. Divê meriv dîyar bike ku erebên kurmancîaxiv, di axaftina xwe ya kurmancî da zayenda makî ya heyberan zêde bi kar naynin; ew bi giştî meyla xwe didin ser zayenda nêr. Ev jî dibe ku ji ber hêsanîyekê be. Çunkî zayenda navdêran di kurmancî da ji bo gelên bi eslê xwe ne kurmanc bin zehmet e. Wekî din, di dawîya sedsala 15an û serê sedsala 16an da herêma Xerzan ketîye bin desthilatdarîya sîyasî-îdarî ya sefewîyan. Zimanê sefewîyên wê hingê farisî ye û farisî, wê hingê dibe ku bûbe zimanê serdest-fermî yê vê herêmê. Îca ev rewşa zimanê farisî ku zayenda nêrî û makîya navan avêtîye, dibe ku li ser kurmancîya vê herêmê jî karîgerî kiribe.

\subsubsection{Bêjeya Xwişk}

Cîyê baldarî û balkêş̂ŷê ye ku bêjeya "xwişk" di piranîya devokên kurmancî da bi awayê "xwişk", "xwing", "xweh" û "xuşk" e; lêbelê di devoka Xerzan da bi awayê "xoy"yê ye. Digel ku di devokên derdora herêma Xerzan da ji bo "xwişk"ê "xwa" jî dibêjin, bes li vê herêmê bi formê "xo" maye.

\subsection{Cihnav}

Di serî da divê em dîyar bikin ku di risteyên vê devokê da koma cihnavên tewandî (min, te, me, we) ji koma cihnavên sade (ez, tu, ew, em, ) zêdetir tên bikaranîn. Axiverê vê devokê, gava risteyekê saz dike, li şûna ku bibêje "Ez çûm." dibêje: "Min çû." Ne bi awayekî sîstematîk be jî, çawa ku di kurmancîya xwarê da cihnava "ez" nayê bikarênan, di vê devokê da jî meyleke mezin li ser cihnava "min" heye.

\subsubsection{Cihnava "Xo"}

Cihnava "xwe" ku di piranîya devokên kurmancîyê da bi awayê "xwe, xwu, xwi, xu" ye; di devoka herêma Xerzan da tim û tim bi teşeyê "xo" ye. Heta gava di nav bêjeyên pevedudanî jî da cih digire, bi awa û formata "xo" cih digire û naguhere:

Serbixo, jixo, bi xo, xo bi xo

Formata cihnava "xo" heman mîna formata "xo"ya kirmanckî û soranî ye. Ne li hemû herêma Xerzan; bes li derdora Sason û Hezoyê wiha ye.

\subsubsection{Cihnava "Tu"}

Di devoka hemû herêma Xerzan da cihnava "tu" bi tu awayî venaguhere "ti"; lêbelê di devokên kurmancî yên mîna Dîyarbekir û Mêrdînê da dibe "ti". Ev 
cihnava "tu" ne zirav e jî, tam bi awayê kurmancîya jêrîn e û hinekî stûr û dirêj e. Em ji çavkanîyan (Gultekîn, 2010: 45) hîn dibin ku ev cihnava "tu" di kirmanckî/zazakî da jî veguherîye teşeyê "ti". Wusa xuya dike ku li vir, di bikaranîna dengdrêra kurt " $u$ " û "i”"yê da arîşeyek heye. Ji ber ku di kurmancîya jorîn da "tu" û di ya jêrîn da ev format di rengê "to"yê da ye (Kurdo, 2013: 118), bi qenaeta min heq heye ku di kirmanckî da jî ne formata "ti"; bes formata "tu" bihe tercîhkirin.

\subsubsection{Cihnava "Me"}

Ev cihnava kesê yekem ê zafhejmarî "me" bi lêkera "çû"yînê ra zêde tê bikaranîn: $M e$ çû.

Nabêjin em çûn; dibêjin me çû. Digel vê, gava yekî Hezoyî vê cihnavê bi lêv dike, nêzî dengê "ma" bi lêv dike. Cihnava "ç̂̀" jî forma xwe diparêze: Tu hatî $c ̧ \hat{\imath}$ ?

\subsection{Hevalnav}

\section{Çi - Çî}

Di nav axiverên Misirc-Gurdilanî da jî cihnava "çi”" bi awayê "çî" tê bikaranîn. Di devoka Kurtalanê da devoka Xerzanîyê, bi awayekî îstîqrar cih nagire; ji herêma Torê jî û ji herêmên din jî axivgêr hene. (Hevpeyvîna bi Îbrahîm Tarduş).

Di devoka Qoser Mêrdînê da "çîk"; di ya Deşta Gewran da "çer" e. Mîna dîyalekta babanî û kurmancîya jêrîn di formata "çî" da ye.

\subsection{Bêjeya "Mam" û "Ap"}

Bêjeya "mam", li vê herêmê mîna soranî ye; bêjeya "ap" di devokên din ên kurmancî da heye; di devoka Xerzan da tuneye. Gava ev bêjeya "mam" dikeve nav bêjeyên ku binyada wan ji bêjeyên pevedudanî pêk hatine jî, ev bêje naguhere:

\section{Mamojin, kurmam, pismam, keçmam, mamo}

\section{Sentaksa Devoka Xerzan}

Di risteyên vê devokê, hinek taybetmendîyên xweser hene ku devokên din ên kuremancî da xuya nakin. Bi piranî gava biker bibe cihnava "em", li şûna wê, riste bi cihnava "me"yê dest pê dike: "Me çû gund ew dîtin."

\subsection{Lêkera/Karê Alîkar "be" - "bî"}

Digel ku di piranîya devokên kurmancî da lêkera/karê alîkar "bû" gava tê ser bêjeyeke navdêr/nav, bi formata "be/bi" ye û di devoka Torê da "bê" ye; di dîyalekta kirmanckî da "bo" ye; di devoka herêma Xerzan da bi şiklê "bî" ye: Qewet bî ji we re. 
Yekî ku tam munafiq bî, çavê xwe dikî bin emrê xwe. Yekî ku ne munafiq bî, girîyê wî bê, nasekinî. (Wext Çawa Derbas Bû, Şêx Marûf Yıldırım, 01.03.2017)

Gava di vê devokê da yek dibêje "Qewet bî." dîyar e ku bi nîyeta duayê, lêkera alîkar "be"yê ditewêne û wekî ku bibêje: Hêvîdar im tu bi qewet bî."

Ev formata ku di devokên din da bi awayê "Qewet be.” ye, di devoka Xerzanîyê da vediguhere "Qewet bî." dibe ku ji hêla sentaksê/ristesazîyê ve risteyeke duayî be, lewra ketîye vî teşeyî. Muminekî/e kurmanc gava dua dike, Xwedayê wî/wê, jê ra serdest e, raser e, lewra nikare lê ferman bike, tenê wekî daxwaz dibêje: "Ya Rebbî, ez dixwazim tu qewetê bidî wî."

Yaxud qesda wî/wê wiha ye: "Ya Rebbî, heger tu qewetê bidî wî baş e."

Yekî ereb, gava dua dike dibêje: "Ellahumme exfirlî.” اللهم اغفرلى [Rebbê min, min bixefirîne.]; yekî tirk gava dua dike, dibêje: "Allahım beni beni affet."; lê yekî kurmanc, wekî ku bi heddê xwe bizanibe, risteya xwe ya duayî, li ser bingeha raweya daxwazî saz dike. Digel vê rewşê, fiîla alîkar "bû-“" di devoka herêma Botan da bi awayê "buwîn" tê bikaranîn. Dibe ku ev awayê ha, bi domana demê ra ji "bûyî"nê" veguherîbe bûwî" > "buwî" > "bî"yê.

\subsection{Lêkera/Karê "Fer"-în}

Di xebata xwe ya li ser devoka Xerzan da em rastî fî̂lekê hatin ku tenê xasî bi axiverê vê devokê ye: fer-în. Gava yekî herêma Xerzan dibêje "ferê", wate li min binihêre, dêhn û bal û haya xwe bide min. Ev karê ferê, ji bilî vê devokê, me di tu devokeke din a kurmancî da nedît. Her çendî di metnên nivîskî yên helbestên ehlê medreseyê da ev kar bi awayê fermûyîd tê bikaranîn (ئامدى ؟ 64). Îro çi di nav axaftina rojane da be, çi jî di nav metnên nivîskî da meriv rast li vê bêjeyê nahê. Digel vê dibe ku ev bêje, têkildarî bêjeya fêrbûnê be jî. Gava axiverekî/e Xerzan di weqtê axaftinê da ji kesê pêşberî xwe ra dibêje ferê, dîyar e ku jê ra dibêje guhdarî bike û hîn bibe. Mîna ku bibêje fêr bibe. Digel ku îro di kurmancî da fî̂la "ferm-" di rewşa fermanî/emrî da bi awayê "fermo" tê bikaranîn, bi qenaeta min xelet e. Divê ku bi awayê "biferme" be. Çunkî ev formata ku bi "bi-"yê dest pê dike, (bixwêne, bireve, bimeşe) di hemû fîilên fermanî yên kurmancî, soranî û kirmanckî da berbelavtir e. Heta em dibînin ku di zimanê farisî da jî bi heman formatê, ango bi awayê "bi-ferma-y-îd" e: "Aqayê Îzdî, bifermayîd înca." ( ثمر ه، 1990: 85

\subsection{Formata Gireya Kesê Duyem ê Yekhejmarî û Kesên Zafhejmarî}

Li herêma Gurdilan û Hezoyê, ew gireyên kesan ên mîna hatîye, hatine, bi awayekî rêkûpêk, "-e/-ye" û "-ine” ye. Mîna herêmên din ku meyla van gireyan diçe ser dengê "-i/yi” û "-ini” nîne: Ew ji Misircê hatîye. Ew ji Babosîyê hatine. (H. Î. Tarduş)

\section{Encam}


Piştî raxistina rabirdûya dîrokî ya herêma Xerzan û raberkirina taybetmendîyên wê yên cografî, demografî û devokî, digel herêmên din ên dîyalketên kurdî, ne bi temamî be jî, dîyar bû ku devoka Xerzan a kurmancî, çawa ku ji hin hêlên fonetîk, fonolojîk, morfolojîk, gramerî û sentaksî ve ji devokên din ên kurmancî cîyatir bûye, pê ra jî şibîyaye kurmacîya xwarê. Herêma Xerzan, ji qedîmî zeman ve bo qewmên qedîm malovanî kirîye. Hîna ji berî mîladê ve bûye cîyê şênîyên medenî. Ji serdema Bîzansî, Romayî, Xelîfeyên Îslamê, Emewî, Ebbasî, Merwanî, Eyyûbî, Artûqî, Selçûqî, Akkoyunî û Sefewîyan ve jîyana civakî şaristanî li vir hebûye. Piştî serdema mîrektîyên kurd, êdî ev dever ketîye bin desthilatdarîya Osmanîyan.

1. Tîpa [a]yê ji alîyê fonetîka xwe ve çawa ku ne mîna ye fonetîka devokên din ên kurmancîya jorîn, wisa jî bi xurtî û zelalî dişibe kurmancîya jêrîn/xwarê, ango kurdîya naverast. Tîpên dengdêr ên kurt ên mîna [e], [i], [u] ku di devoka Xerzanîyê da tên bikaranîn, digel ku hinekî dişibin devoka herêma TorêMêrdînê, dîsa bi meyleke mezin di dirûvê axiverên dîyalekta kurmancîya xwarê da ne.

2. Herfên nedengdêr ên devoka Xerzan bi temamî ji devokên din ên kurmancî cîyatir in, nerm û lawaz nînin; bes heman mîna nedengdêrên kurmancîya xwarê, bi şipil û çeleng in. Di vê çelengî û şipişîyê da dibe rista cografî jî hebe.

3. Zayenda makî, heman mîna kurmancîya xwarê ji nav devoka Xerzan rabûye. Sedemê vê jî dibe ku ji ber karîgerîya desthilatdarîya sîyasî ya zimanê farisî, yan karîgerîya awayê axaftina erebên kurmancîaxiv, an jî meyla xelasbûna ji bargiranîya taybetmendîyên zayendê be. Devoka Xerzan, ji alîyê zayendê ve çawa ku dişibe zayenda kurmancîya jêrîn, dîyar e ku dişibe kurmancîya Şêxbizinîyên dormedora Semsûr û Konyayê jî.

4. Cihnava "xwe" di vê devokê da tam bi awayê formata kurmancîya xwarê, "xo" ye. Gava kurmancîaxivên vê deverê bi cihnava "xo" bêjeyên nû saz dikin, dîsa formata wê ya bi teşeyê "xo" diparêzin.

5. Hudûdê devoka Xerzan, di nav herêma Xerzan bi xwe da jî lokal e. Digel ku cografyaya herêma Xerzan ji hêla gund û devokên xwe ve xwedî dewlemendî û rengînîyê ye û li gundên derdora wê eşîrên mezin ên mîna Xîyan, Reşkotan, Elikan û Bekiran hene jî, dîsa ev herêm gişt ne bi heman tarz û teherî dipeyive. Devoka Xerzan, tenê xasî bi şarçeyên mîna Hezo/Kozluk, Hewêl/Baykan, Misircê/Kurtalan û Sasonê ye.

\section{Çavkanî}

Aşan, M. B. (1993). Van Yöresi üzerinde Yapılan Tarih Araştırmaları ve Bazı Düşünceler. İstabul: Türk Dünyası Araştırmaları Vakfı.

Beg, M. E. (2010). Dîroka Kurd û Kurdistanê, (Ji Soranî bo kurmancî: Zîya Avci). İstanbul: Avesta. 
Efendi, A. A. (1280). Der Hülasai Mezamin-i Defter-i Divan. İstanbul: Tasvir-i Efkar Gazetesi Matbaasi.

Emîn, W. ‘. (2009). Asoyekîtirî Zimanewanî, (Bergî Yekem). Hewlêr: Aras.

Falay, F. B. (2007). Siirt'in 19. yüzyıl Sonlarındaki Sosyo-Ekonomik Yapısı.

Uluslararas1 Siirt Sempozyumu, (s. 153). İzmir.

Gultekîn, S. (2010). Ro Ser ZArawaya Kirmanckî Xebata Gramerî. Îstanbul: Weşanên Enstîtuya Kurdî ya Stenbolê.

İbrahim Bingöl Mardin. (2017). Cihnav di Zazakiya Gimgimê de. The Journal of Mesopotamian Studies, 90.

Komisyon. (1998). 1998 Yılı Batman İl Yıllı̆̆ı . Batman: Batman Özel İdaresi.

Komisyon, H. . (2011). Batman İli Sosyo-Ekonomik Profili. batman: Batman Ticaret ve Sanayi Odası Yayını.

Kurdo, Q. (2013). Rêzimana Kurdî (Kurmancî-Soranî) (Ji Kurdîya Soranî: Zülküf Ergün). İstanbul: Nûbihar.

M. Salih Batirhan. (2014). Şêxbizinîyên Haymanayê û Zarê Wan. Zend, 85.

Naîma, M. (2018). Sason Aşîretlerinin Dağılımı.

http://www.sasun.org/kultur/gunumuz-sason-asiretlerinin-dagilimi-

h731.html.

Öztuna, Y. (1969). Devletler ve Hanedanlar (Türkîye, 1074-1990) c. II. Ankara:

Kültür Bakanlığı Yayınları.

S. Sönmezsoy, Y. E. (1994). Siirt Tarihi (Başlangıçtan Osmanlîya Kadar). Van:

YYÜ Ferit Melen Kütüphanesi (Basilmamiş).

Sami, Ş. (1996). Kâmûsu'l-A'lâm, IV . Ankara: Kangar Neşrîyat.

San, M. S. (1982). Doğu Anadolu ve Muş'un İzahlı Kronolojik Tarihi. Ankara: Türk Kültürünü Araştırma Enstitüsü.

Saraçoğlu, M. Z. (2007). 19. Yüzyıldan Günümüze Siirt İlinin İdari ve

Demografik Yapısında Meydana Gelen Değişmeler. Uluslararası Siirt Sempozyumu, (s. 622-630). İzmir.

Turan, O. (1973). Doğu Anadolu Türk Devletleri Tarihi. İstanbul: Turan Neşrîyat.

Xoşnaw, N. E. (2013). Dengsazî, (çapa yekem). Hewlêr: Çapxaney Rojhelat.

Yıldız, H. D. (1976). İslamîyet ve Türkler. İstanbul: İstanbul Üniversitesi Edebîyat Fakültesi Yayını.

Yıldız, H. D. (1982). Anadolu Türk Tarihi. Anadolu Uygarlıkları Ansiklopedisi, (c. 4, 630). İstanbul: İstabul Ünüversitesi Edebîyat Fakültesi Yayını.

Yılmazçelik, İ. (1995). XIX. Yüzyılın İlk Yarısında Dîyarbakır, (1790-1840).

Ankara: Türk Tarih Kurumu Yayınları.

Yücel, A. S. (1989). Türkîye Tarihi. Ankara: Türk Tarih Kurumu Yayınları.

Zîllî, E. D. (2006). Seyahatname III-IV, T. Temelkuran, N. Aktaş, ve M. Çevik

(Çev). . Îstanbul: Üçdal Neşrîyat.

بيروت: دار المعرفة ـ محاضرات تاريخ الئمم الئسلامييية الدولة الامويية . (2005/1426) .الخضرى, م

بيروت : دار القلم . محاضرت تاريخ الئمم الاسلامية الدولة العباسية .(؟) .بك, م. خ 


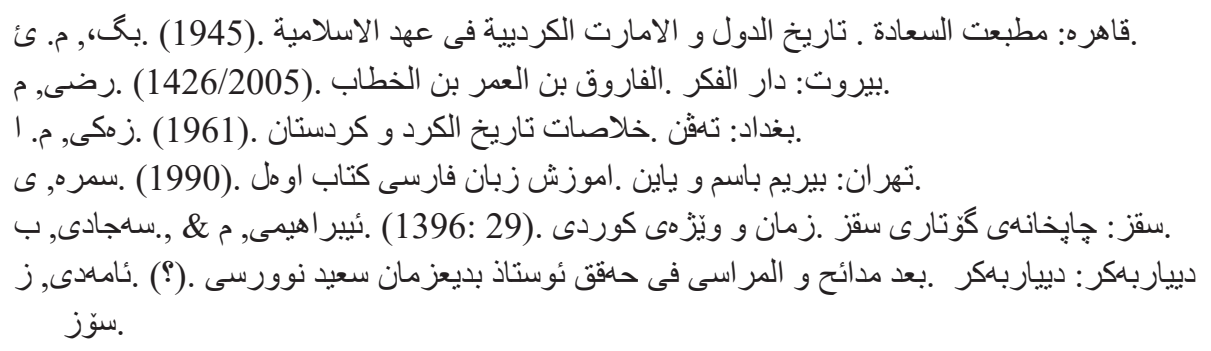

\section{Transkrîpeya Çavkanîyên Erebî, Farisî û Kurdî yên bi Alfabeya Erebî}

Amedî, Zeynelabidin Be‘du'l-Medaihi we'l-Merasî fî̀ Heqqi Ustaz Bedîuzzeman Seîd Nûrsî, (Ceme'ehu.), Dîyarbekir: Dîyarbakır Söz.

Bek, M. X. (?). Muhaderatu Tarîxi'l-Umemi'l-1̂slamîyye ed-Dewletu'lEbbasîyye, (Tehqîq: Muehmmed el-‘Usmanî), Beyrût: Daru'l-Qelem.

Emîn, Wirya 'Umer. (2009). Asoyekîtirî Zimanewanî, (Bergî Yekem), Hewlêr: Aras.

Hısn Keyfa Vekainamesi (Nüzhetü'n-Nazır ve Rahatü'l-Hatır), Vîyana Milli Kütüphanesi, Mxs. 355 varak, 76a.

Riza, M. (2005/1426). el-Farûq Umer bin el-Xettab, (Îtîna bih: Nacî Îbrahîm esSiweyd), Beyrût: Daru'l-Fikir.

Xoşnaw, Nerîman Ebdulla. (2013). Dengsazî, (çapa yekem), Hewlêr: Çapxaney Rojhelat.

Zeki, M. E. (1961). Hulasatu Tarihi'l-Kürd ve Kürdistan, Muhammed Ali Avni (Arapça'ya Terceme), 2. Baskı, Bağdat: Tevin.

Zekî, M. E. (1945/1364). Tarîxu'd-Duweli we'l-Emaratu'l-Kurdîyyeti fî 'Ehdi'lÎslamîy, ('Errebehu we Raci'ehu: Muhemmed 'Elî 'Ewnî), Qahire: Metbeetu's-Seadet.

\section{Çavkanîyên Înternetê}

Erzurumlu, K. (2015), Osmanlıdan Günümüze Kürt Sorunu 3, www.sedîyani.com/p? (31.10.2018)

https:/www.youtube.com/watch? $\mathrm{v}=-$ wHFPIThb1A\&t=2305s $\quad$ Wext Çawa

Derbas Bû, Şêx Marûf Yıldırım, 01.03.2017, tarîxa gihîştinê, 02.11.2018).

http://www.kozluk.gov.tr/kozluk-tarihcesi (Dîroka pêgihîştinê:

31.10.2018).

https://www.youtube.com/watch?v=inNoUWCHHM0\&t=731s,

abdurrehman inal kozluk (Dîroka pêgihisştinê: 03.11.2018).

http://www.kozluk.gov.tr/kozlukadi (Dîroka pêgihîştinê: 03.11.2018).

Naîma, M. (2018). Sason Aşîretlerinin Dağılımı,

http://www.sasun.org/kultur/gunumuz-sason-asiretlerinin-dagilimi$\underline{\text { h731.html }}(08.01 .2019)$

Kesên Çavkanî yên Zindî

Hevpeyvîna bi Îbrahîm Tarduş re, (31.10.2018) 
Cîyê Fonetîk, Fonolojî̀ $\hat{u}$ Gramera Devoka Xerzan di nav Devokên Kurmancî û̀ Dîyalektên Kurdî da

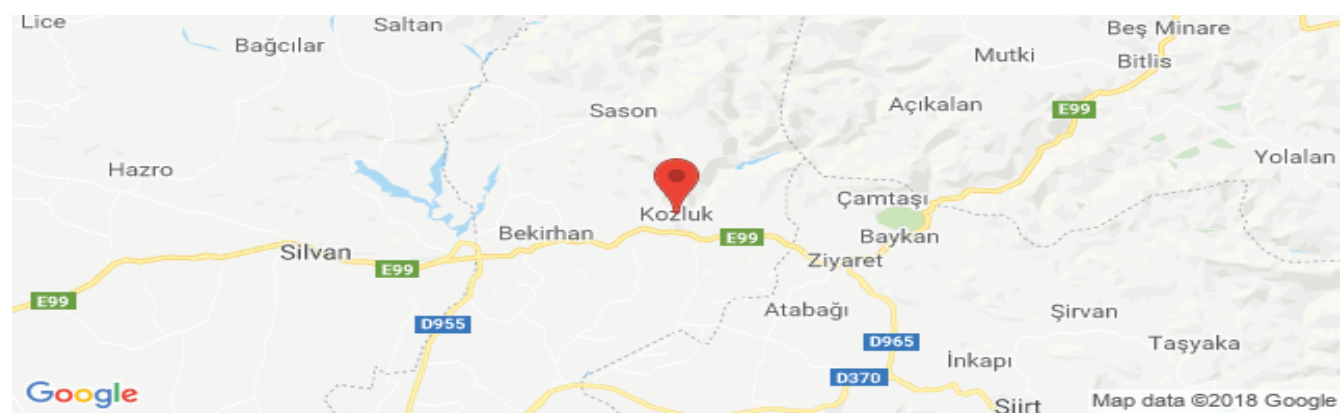

https://www.google.com/search?q=kozluk + haritası\&source=lnms\&tbm=isch\&sa

$=$ X\&ved=0ahUKEwihwY-UlsjfAhXCE $(30.12 .2018)$

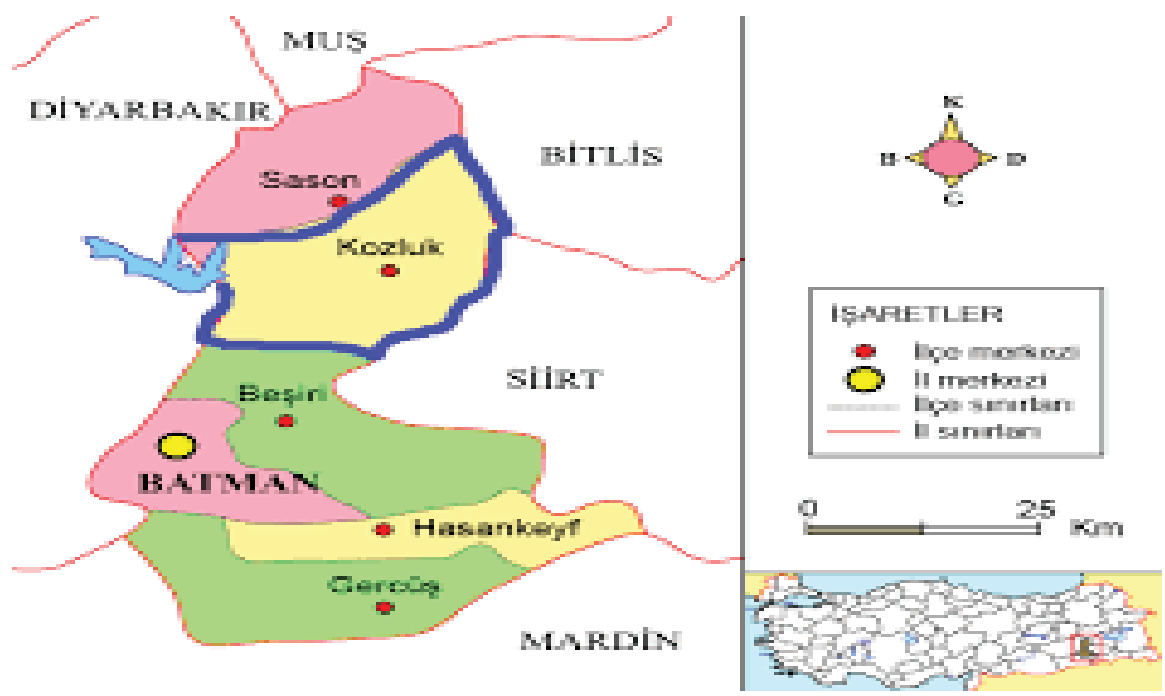

https://www.google.com/search?q=kozluk + haritası\&source=lnms\&tbm=isch\&sa

$=$ X\&ved=0ahUKEwihwY-UlsjfAhXCE (30.12.2018)

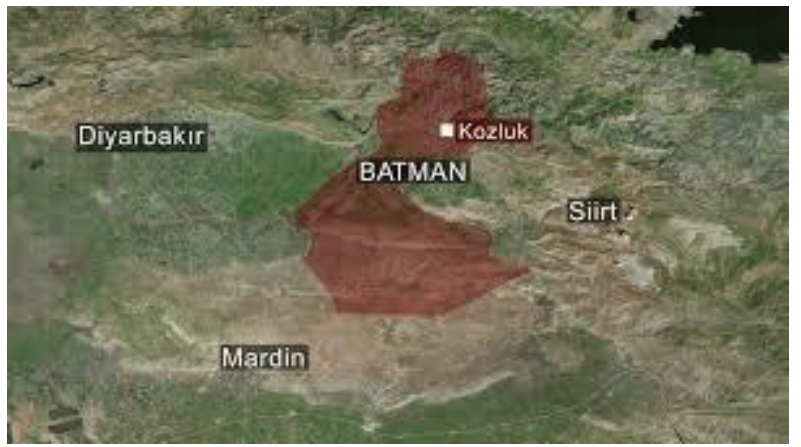

https://www.google.com/search?q=kozluk+haritas1\&source=lnms\&tbm=isch\&sa

$=$ X\&ved=0ahUKEwihwY-UlsjfAhXCE (30.12.2018) 


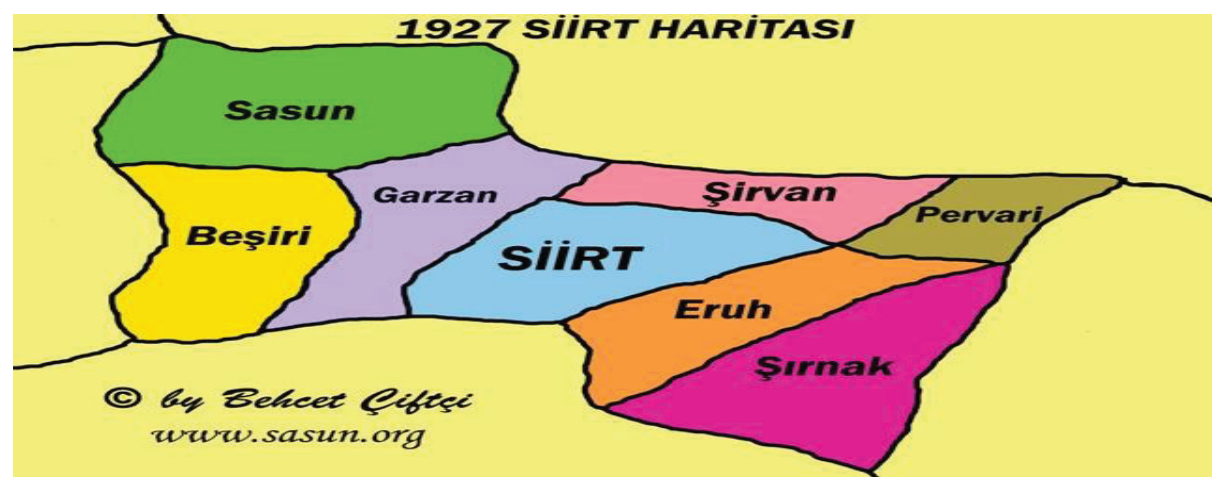

https://www.google.com/search?q=kozluk+haritası\&source=lnms\&tbm=isch\&sa

$=$ X\&ved=0ahUKEwihwY-UlsjfAhXCE (30.12.2018)

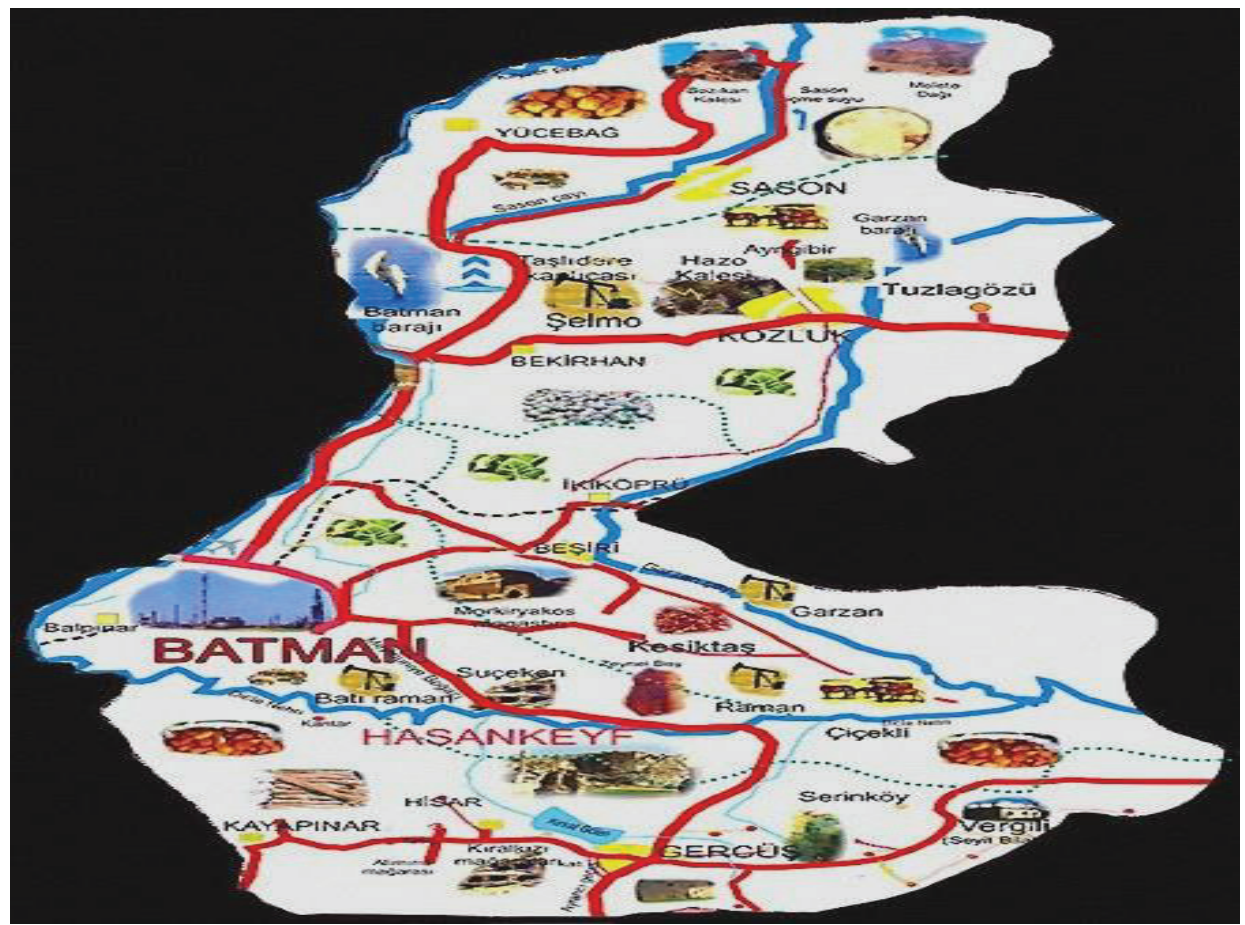

https://www.google.com/search?q=kozluk+haritas1\&source=lnms\&tbm=isch\&sa

$=$ X\&ved=0ahUKEwihwY-UlsjfAhXCE (30.12.2018) 
Cîyê Fonetîk, Fonolojî̀ $\hat{u}$ Gramera Devoka Xerzan di nav Devokên Kurmancî û̀ Dîyalektên Kurdî da

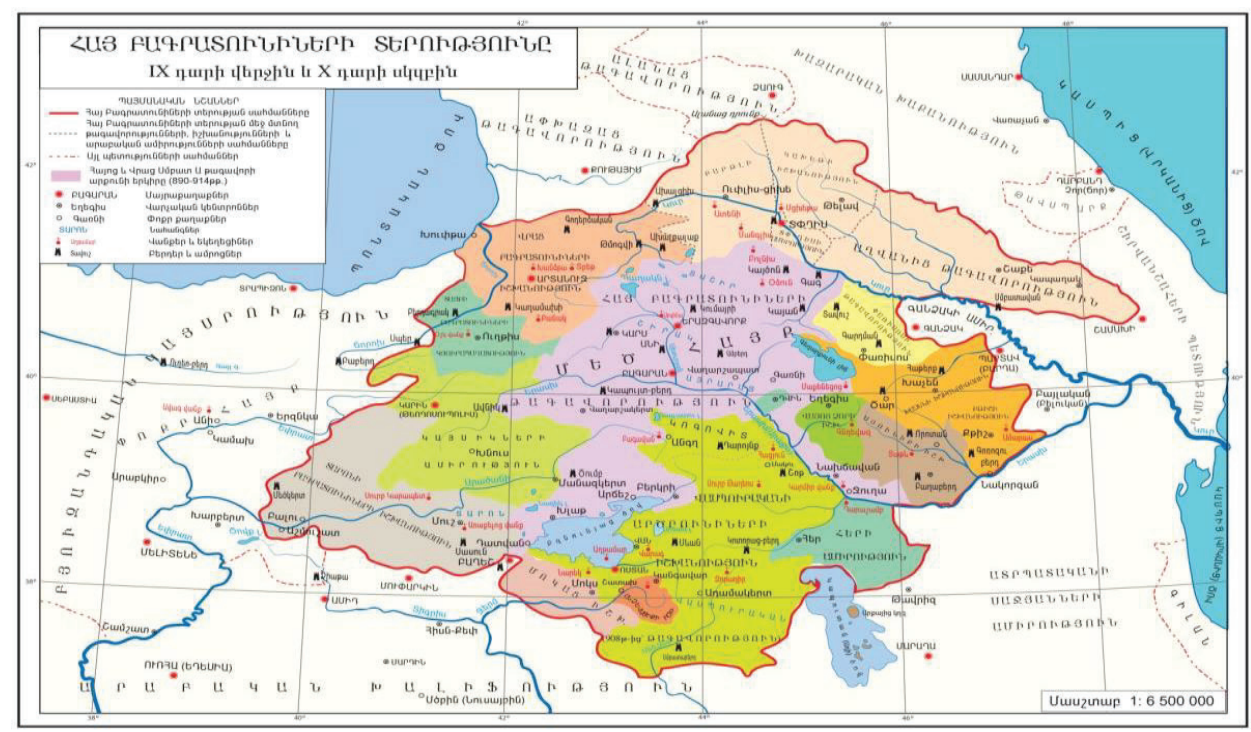

http://www.sasun.org/kultur/gunumuz-sason-asiretlerinin-dagilimi-h731.html $(07.01 .2019)$ 